\title{
Unilateral Ectopic Kidney During Paraaortic Lymphadenectomy: A Case Report
}

\section{Paraaortik Lenf Nodu Diseksiyonu Sırasında Unilateral Ektopik Böbrek}

\author{
Adem YAVUZ ${ }^{1}$, Cevat Rıfat CÜNDÜBEY ${ }^{2}$, Mehmet DOLANBAY ${ }^{3}$
}

${ }^{1}$ Niğde Ömer Halisdemir University, Department of Obstetrics and Gynecology, Niğde

${ }^{2}$ Kastamonu Taşköprü State Hospital, Department of Obstetrics and Gynecology, Kastamonu

${ }^{3}$ Erciyes University, Faculty of Medicine, Department of Obstetrics and Gynecology, Kayser

\begin{abstract}
The incidence of ectopic kidney is approximately 1:1,000 in newborns. Ectopic kidney has a place outside of renal fossa and been found in the pelvis, abdomen, and thorax. We reported a case of a 51-year-old female who was referred to our hospital with the complaint of abnormal vaginal bleeding and pelvic pain. Adenocarcinoma of cervix was reported after biopsy, radical hysterectomy and bilateral salphingo-oopherectomy with pelvic and para-aortic lymph node dissection were performed. Unilateral, right renal ectopic kidney with vessels was observed during paraaortic lymphadenectomy in cervical cancer surgery. During gynecological oncologic surgery especially at the retroperitoneal stage congenital organ abnormalities must be kept in mind and surgery must be planned according to the abnormalities.
\end{abstract}

Keywords: Cervical Cancer, Kidney, Renal Ectopic Kidney

\section{Öz}

Ektopik böbrek; yenidoğanda yaklaşık 1/1000 oranında görülen, renal fossa dişında pelvis, abdomen ve toraksta bulunan anormal yerleşimli böbreği tanımlar. Anormal uterin kanama ve pelvik ağrı şikayeti ile başvuran 51 yaşında kadın hastadan alınan serviks biyopsisi adenokarsinom olarak rapor edildi. Hasta onamı alınarak radikal histerektomi, bilateral salpingo-ooferektomi ve pelvik paraaortik lenf nodu diseksiyonu yapıldı. Cerrahinin paraaortik lenf nodu diseksiyonu aşamasında damarları ile birlikte unilateral renal ektopik böbrek tespit edildi. Onkolojik cerrahilerde özellikle de retroperitoneal bölge aşamasında komplikasyon oranlarını en düşük düzeylere indirmek için doğumsal organ yerleşim anomalileri akılda bulundurulmalı ve cerrahi planlaması yapılmalıdır.

Anahtar Kelimeler: Böbrek, Ektopik Böbrek, Serviks Kanseri

\section{Introduction}

Kidney, which has a place outside of renal fossa, is called renal ectopia. Normally the kidneys are located in the lumbar region of retroperitoneum. The upper pole of the left kidney is placed at the level of the T11 vertebra, whereas the upper pole of the right kidney lies at a lower level, at the level of the T11$\mathrm{T} 12$ intercostal space. The variations in the number, shape, size, position, rotation and the vascularization of the kidneys are of immense importance due to their susceptibilities (1).

An ectopic kidney might be found in the pelvis, abdomen, and thorax. Renal ascension is correlated with vascularization and renal ectopia is also associated with anomalies in renal vessels. Ectopia or rotation anomalies are originated form malascension of the renal arteries (2).

Unilateral renal ectopia is rare (1:1000-1:3000 births) and according to the lacks of specific symptoms it might be discovered during unrelated examination (3).

\begin{tabular}{|c|c|}
\hline & ORCID No \\
\hline Adem YAVUZ & 0000-0003-4191-4004 \\
\hline Cevat Rifat CÜNDÜBEY & 0000-0002-7248-779X \\
\hline Mehmet DOLANBAY & 0000-0002-8332-1568 \\
\hline Başvuru Tarihi / Received: & 17.07.2019 \\
\hline Kabul Tarihi / Accepted : & 15.12.2019 \\
\hline Adres / Correspondence : & Mehmet DOLANBAY \\
\hline $\begin{array}{l}\text { Erciyes University, Fact } \\
\text { Obstetrics and Gynecology }\end{array}$ & $\begin{array}{l}\text { of Medicine, Department of } \\
\text { ayseri }\end{array}$ \\
\hline e-posta / e-mail & mehmetdolanbay@yahoo.com \\
\hline
\end{tabular}

We present a case with unilateral, right renal ectopic kidney with vessels was observed during the routine para-aortic lymphadenectomy in cervical cancer surgery.

\section{Case Report}

A 51-year-old female, presented with abnormal vaginal bleeding and pelvic pain with a two-week history was referred to the gynecology department. In the pelvic examination, a 4-cm exophytic, cancerous lesion was found in the uterine cervix that extended into the cervical canal. Vaginal fornix and parametrium were not involved. She had no family history of any gynecologic, breast, or gastrointestinal malignancies. We performed a punch biopsy of the cervix, and it was reported as adenocarcinoma of cervix. For staging work-ups, complete blood counts, blood chemistry, chest X-ray were performed. 18F-fluorodeoxyglucse (FDG) positron emission tomography (PET/CT) was also performed. It demonstrated significant uptake in the mass 8 centimeters to 6 centimeters on cervix. There is no evidence of distant metastasis or any suggestive metastatic lymph node. Clinically, stage IB was suggested and radical hysterectomy, bilateral salphingo-oopherectomy with pelvic and para-aortic lymph node dissection was performed. In exploration uterus was larger than normal, there was not any adnexal pathology, and there were no enlarged pelvic para-aortic lymph nodes or ascites. During the para-aortic lymph node dissection, we encountered one artery and 2 veins, one centimeter 
under inferior mesenteric artery. They were thought to be ovarian artery and ovarian vein. When adipose tissue was dissected, right ectopic kidney with ureter was detected. Kidney was located between the levels of L2-L3 to L4-L5 intervertebral space.

The right kidney was vascularized from the right renal artery which originated from the lateral side of the abdominal aorta at the level of L3 vertebral body. The left kidney was in the normal position.

Histopathological examination revealed a good differentiated, 6 to 2.5 centimeters adenocarcinoma of the cervix with 9 millimeters invasion depth. The mass was extending from cervix to uterin corpus with an invasion of endocervix and ectocervix. There was only metastatic tumor in sections taken from right pelvic lymph nodes. The removed vagina and all remaining resection margins were clear. Radiotherapy and brachytherapy were performed postoperatively due to size of the mass prior than lymph node positivity.

\section{Discussion}

There are two different ideas identifying the position of the kidneys in the literature. In the first hypothesis, the kidney ascends in the retroperitoneal area during ontogenetic development. The renal rudiment occurs in the pelvic region at the level of L2-L3 vertebrae. The kidney goes to the definite position according to the process of ascension and rotation.

During the 6th and the 9th week of fetal development, the kidney ascends to the lumbar region. Although the mechanism is not well-known, some substance secretes from the developing kidney may play a role in this movement. In the second hypothesis, the kidney undergoes pseudo ascension according to the fast development of the caudal body part of the fetus (4).

The renal development might be affected by genetic factors, chromosomal anomalies, teratogenic agents, medicines, disorders in the fusion mechanism of the ureteric bud and the metanephrogenic blastema (5).

In the literature, there have been lots of idiopathic cases (6). Simple ectopia might be occurred after the two kidneys have separated completely. The ectopic kidney might be located in the pelvis, abdomen, and the thorax and also might be unilateral or bilateral.
In the literature, the most frequent cases of renal ectopia described male's right side of the pelvis (7). An ectopic kidney is mostly found in small irregular shape and variable rotation and vascularized by multiple arteries with the different origin.

Uterine cervical cancer is the second most common gynecological malignancy (8). The cervical cancer is generally characterized by local invasion through interstitial spaces of the pelvic tissue and by circulatory pathway of lymph dissemination through the lymph nodes of uterus and cervix. Surgical staging has been demonstrated to be the best option for establishing the status of para-aortic node in women with cervical cancer. Standard treatment for patients with early stage cervical cancer is radical hysterectomy, pelvic and para-aortic lymphadenectomy. This has the risk of intraoperative accidents and postoperative associated morbidity.

In conclusion, during the radical surgery operations accidental damage of the small intestine, colon or bladder or vessels might be occurring. However, the ectopic renal tissue with vascular involvement was rare condition and might be careful during the para-aortic lymph node dissection in the gynecologic surgery.

Written Consent: Written consent was taken from patient on 10.06.2019.

\section{References}

1. Zăhoi DE, Miclăuş G, Alexa A. Ectopic kidney with malrotation and bilateral multiple arteries diagnosed using CT angiography. Rom J Morphol Embryol. 2010;51(3):58992.

2. Das S, Amar AD. Ureteropelvic junction obstruction with associated renal anomalies. J Urol. 1984;131(5):872-4.

3. Krishnaveni C, Kulkarni R. A right ectopic kidney with bilateral multiple anomalies of the renal vasculature - a case report. J Clin Diagn Res. 2013;7(1):150-3

4. Patten BM. Human Embryology. McGraw-Hill Book Co., New York-Toronto-London; 1953.

5. Guidoni P, Embryologie, Editions Doin Deren et Cie Paris, 1968.

6. Gödde S, Die Beckenniere, Dtsch Med Wochenschr. 1968;93(20):1013-7.

7. Campell MF, Harrison JH (eds), Urology, 2nd edition, W.B. Saunders Co., Philadelphia, 1970.

8. Siegel R, DeSantis C, Virgo K, et al. Cancer treatment and survivorship statistics, 2012. CA Cancer J Clin. 2012;62: $220-41$. 